\title{
Die beweging vir kerkvereniging tussen die drie Afrikaanse gereformeerde kerkgemeenskappe in die 20ste eeu: 'n vlugtige oorsig
}

\author{
A.D. Pont \\ Dept. Kerkgeskiedenis (Afd. A.) \\ Universiteit van Pretoria \\ PRETORIA
}

\section{Inleidend}

Hierdie oorsig is ' $n$ herdenking én in ' $n$ sekere sin ' $n$ oorweging van die kerkvereniging van 17 Junie 1892 toe die Nederduitsche Gereformeerde Kerken, wat as dolerende kerke uit die gemeenskap van die Nederlandse Hervormde Kerk getree het, en die Christelijke Gereformeerde Kerken wat in 1834 afgeskei het, saain 'n nuwe kerkverband gevorm het. Die nuwe kerkverband het toe die naam De Gereformeerde Kerken in Nederland aanvaar (Bakhuizen van den Brink, 1962:II:338). Skynbaar was dit nie moeilik gewees om die vereniging te verwerklik nie (De Jong, 1978:359). Reeds by die Synodaal Convent wat die dolerende kerke aan die einde van Junie 1887 in Rotterdam gehou het, is gestel dat daar gesoek moet word na die oprigting van een kerkverband met "... de geloovigen die nog onder de Hierarchie bleven, en even zoo de broeders uit de kerken van Ledeboer, en in de Chr Ger Kerk en andere Vrije Kerken ..." (Bakhuizen van den Brink, 1962:II:336). Dié ideaal het vanaf 1891 ernstig aandag gekry en mettertyd is al die probleme uitgestryk sodat die vierde voorlopige sinode van die Nederduitsche Gerefonneerde Kerken in 1892 kon besluit om saam met die Christelijke Gereformeerde Kerken een kerkverband te vorm. Die basis waarop die vereniging plaasgevind het, was in hoofsaak: "... de grondslag van de gemeenschappelijke belijdenis der Drie Formulieren van Eenigheid, van de Gereformeerde Kerkenordening (laatstelijk in 1619 bevestigd) ..." en dan die verdere sake waaroor ooreengekom is. Hoewel daar ook besware was (Reitsma \& Lindeboom, 1949:512) en die predikante Van Lingen en J. Wisse nie saam met die vereniging gegaan het nie, het die Gereformeerde Kerken in Nederland in 1892 begin as 'n groot kerklike gemeenskap wat volledig op sy eie bene kon staan.

As daar vandag, iets meer as 'n honderd jaar later, op daardie vereniging teruggekyk word, is dit wel duidelik dat selfs hierdie byna vanselfsprekende kerk- 
vereniging nie werklik in alle opsigte kerklike eenheid geskep het nie. Die Christelijke Gereformeerde Kerken wat in Januarie 1893 hulleself gereorganiseer het as "... de zuivere voortzetting der aloude Christelijke Gereformeerde Kerk, gelijk zij in de dagen der Afscheiding is herleefd ..." (Van Veen, 1904:567), het daarop gedui dat dit feitlik onmoontlik is om twee kerklike gemeenskappe, elkeen met ' $n$ eie kerklike aksent en lewenstyl, in een gemeenskap saam te vat.

Aan die ander kant is dit ook waar dat die kerkvereniging van 1892 'n groot bydrae gelewer het tot die verdere ontplooiing van die gereformeerde teologie, kerklike bewussyn en lewenstyl, in Nederland en in Suid-Afrika.

As daar nou, in die dampkring van die herdenking van die grotendeels suksesvolle kerkvereniging van 1892 in Nederland, gekyk word na die beweging vir kerkvereniging tussen die drie Afrikaanse kerke, dan is dit gou duidelik dat ons in Suid-Afrika met ' $n$ volkome ander stel omstandighede te make het.

* Die eerste belangrike saak wat in gedagte gehou moet word, is dat die afsonderlike bestaan van die drie Afrikaanse kerke ' $n$ saak is wat al 'n vaste vorm aangeneem het. Die drie kerke, hoewel al drie dieselfde belydenisskrifte aanvaar, lê tog baie beslis ten opsigte van die leer, die diens en die tug hulle eie aksente wat nie altyd so maklik versoenbaar is nie.

* Die tweede saak wat miskien ook in gedagte gehou moet word, is dat in 1885 daar reeds 'n poging tot kerkvereniging tussen die Nederduitse Gereformeerde Kerk en die Nederduitsch Hervormde Kerk in die destydse ZuidAfrikaansche Republiek was. Die mislukking van daardie kerkvereniging het, veral in die Nederduitsch Hervormnde Kerk, bepaalde versigtighede ten opsigte van die hele begrip kerkvereniging laat ontstaan en daardie versigtigheid is in die Nederduitsch Hervormde Kerk nog beslis baie lewend.

* Die derde saak is dat die bestaan van die Tussenkerklike Kommissie en die voortgaande interkerklike gesprek daar, al geweldig baie gedoen het om die saak van kerkvereniging 'n duidelike gestalte te gee, al is dit op die oomblik nog net in die vergaderings van die ampte.

\section{Die eerste skredes na beter begrip en samewerking}

Net voor die uitbreek van die Engelse oorlog in Oktober 1899 was die verhoudinge tussen die Nederduitsch Hervormde Kerk, die Nederduitsch Hervormde of Gereformeerde Kerk en die Gereformeerde Kerk in die ou Republiek op 'n taamlike laagtepunt (Borchardt, 1974:181-186). Onmiddellik na die oorlog, in 1903, het ouderling A.D.W. Wolmarans op die Algemene Kerkvergadering van die Nederduitsch Hervormde Kerk 'n saak uitgemaak vir "toenadering of 'n nouere broederband" (NHK Argief: Notule Algemene Kerkvergadering, 12 Nov. 1903). Die daaropvolgende interkerklike korrespondensie het niks opgelewer nie en die 
hele saak het doodgeloop. Die sinode van die Verenigde Kerk het egter in 1906 en toe weer in 1909 'n kommissie van toenadering benoem om oor beter kerklike verhoudings te onderhandel. Met die Nederduitsch Hervormde Kerk kon oor hierdie saak nie gevorder word nie (Borchardt, 1974:188-189) maar die Gereformeerde Kerk se sinode van 1910 het positief op die voorstel gereageer. Teen die middel van 1913 het die twee kommissies van die Verenigde Kerk en die Gereformeerde Kerk mekaar ontmoet en in die memorandum van die Verenigde Kerk is gestel dat "die einddoel van samewerking van ons kerke, kerkvereniging moet wees" (Borchardt, 1974:191). Op dié punt wou die kommissie van die Gereformeerde Kerk nie ingaan nie maar hulle was wel geneë om oor gemeenskaplike optrede te handel. Die eerste, verkennende gesprek, is egter nie verder gevoer nie. Dit was duidelik dat daar nog heelwat afstand tussen die kerke was en dat dit nie so maklik sou wees om saam te vergader oor samewerking en selfs vereniging nie. Van der Watt (1983:5) sê hieroor:

Die onderlinge verhoudinge het, helaas, meermale ook gestaan in die teken van 'n troebele atmosfeer. Beskuldigings dat die ander kerke die valse kerk is en dat daar toleransie ten opsigte van leerdwalings is, is dikwels gehoor, liberalisme, metodisme en neo-calvinisme is van die etikette, wat verwytend en neerhalend mekaar toegesnou is

Heel dikwels skryf en praat predikante en lidmate van die ander kerke met vooringenomenheid en veel kritiek. Dit is ongelukkig die resultaat van 'n gebrekkige kennis van mekaar én daarby ook die feit dat daardie kennis nie altyd die maksimale objektiwiteit weergee nie, maar gewoonlik dienstig is aan 'n bepaalde kerk se standpunt.

'n Opvolgpoging van die Nederduitsch Hervormde Kerk en die Verenigde Kerk in die jare 1928-1937 om deur middel van kommissies met mekaar te praat, het ook niks opgelewer nie. Dit wil voorkom asof nie een van die twee kommissies werklik 'n doelbewuste poging wou aanwend om met die ander te praat nie (Borchardt, 1974:192-195). Die optrede weerspieël die afstand tussen die twee kerke en dit is duidelik dat die afstand nie maklik oorbrug sou word nie

\section{Samewerking op nie-amptelike vlak}

Terwyl pogings aangewend is om op sinodale vlak toenadering en begrip te kweek en dit maar hortend en stotend voortgegaan het, was daar tog verrassende goeie samewerking op ander terreine. Hier word verwys na die vertaling van die Bybel in Afrikaans wat in 1933 tot stand gekom het, die vertaling van die Drie Fornuliere van eenheid en die Diensformuliere wat ook deur die Bybelvertalers gefinaliseer is en verder die Afrikaanse Psalm- en Gesangeberyming in 1937 en 1944 (Jooste, 1958:373-375). Dit is merkwaardig dat die vertalers uit die drie Afrikaanse kerke mekaar kon vind oor die vertaling van die Skrif maar dat die 
ampsdraers uit die kerke moeite gehad het om mekaar te vind oor die verstaan van die Skrif.

Tog het hierdie vorm van samewerking 'n positiewe uitwerking gehad in die Afrikaanse kerklike wêreld en het daar inderdaad beter begrip vir mekaar en meer samewerking tussen die kerke uit hierdie beter begrip gegroei. Hierdie begrip en samewerking was egter nog nie baie algemeen me en dit was nie moeilik om tussenkerkhike verhoudings te vertroebel nie.

\section{Die Interkerklike Kommissie - 1937-1954}

'n Nuwe inisiatief tot toenadering is in 1933 deur ds. L.E. Brandt, toemalige voorsitter van die Algemene Kerkvergadering van die Nederduitsch Hervormde Kerk onderneem. By ' $n$ vergadering van die Raad van die Nederduitse Gereformeerde Kerke van 8-10 Maart 1933 het Brandt 'n groeteboodskap oorgedra en medewerking gevra vir die oprigting van 'n Interkerklike Kommissie "... wat die gemeenskaplike belange van die drie Hollands-Afrikaanse kerke kon behartig" (Botes, 1989:518-519). Vir dié doel het hy ook aan die Gereformeerde Kerk geskrywe en in 1936 het die sinode van die Gerefonneerde Kerk tot versigtige deelname besluit. In 1937 het afgevaardigdes van die Gereformeerde Kerk en die Nederduitse Gereformeerde Raad van Kerke 'n reglement vir die Interkerklike Kommissie opgestel waar beklemtoon is dat die liggaam alleen as 'n gespreksforum sou dien en dat die onderskeie sinodes hulle oor die kwaliteit van die werk van die Kommissie sou uitspreek (Borchardt, 1974:196). By die Nederduitsch Hervormde Kerk het die saak, ondanks Brandt se bemoeienis, vasgeval en toe die eerste vergadering van die Interkerklike Kommissie op 14 Maart 1939 gehou is, was die Nederduitsch Hervormde Kerk nie verteenwoordig nie. Hierdie toestand sou tot 31 Maart 1942 duur voordat die Nederduitsch Hervonmde Kerk hom by die Interkerklike Kommissie aangesluit het - dit nadat sowel die Gereformeerde Kerk as die Nederduitse Gereformeerde Kerk se sinodes verklaar het dat hulle die Nederduitsch Hervormde Kerk as Christelike kerk erken (Borchardt, 1974:200).

Die Interkerklike Kommissie het met sy eerste vergadering van Maart 1939 al 'n belangrike agenda opgestel. Daar moes gehandel word oor die taak van die kerk na die eeufeesjaar van 1938, volksverdeeldheid en verbittering, die kerk en die FAK, die kerklike tug en die afvaardiging van deputate in adviserende hoedanigheid na mekaar se meerdere vergaderings. Alhoewel die saak van kerklike eenheid nie genoem is nie, is hier 'n poging aangewend om 'n pad na samewerking en beter begrip te bou. 
Dit is interessant dat deur die toedoen van die FAK daar op 3 September 1941 'n vergadering van die Interkerklike Kommissie gehou is, waar gehandel is oor "die verwydering van broedertwis onder die volk" (Borchardt, 1974: 198).

Toe die Nederduitsch Hervormde Kerk op 31 Maart 1942 deel word van die Interkerklike Kommissie, is daar gehandel oor Sondagsontheiliging, die oor en weer erkenning van kerklike lidmaatskap, die erkenning van mekaar se tughandelinge. Hierdie agendapunt dui daarop hoe daar baie versigtig aandag gegee is aan sake waaroor saamgewerk kon word: op hierdie wyse het die Interkerklike Kommissie versigtig én terrein-verkennend vorentoe beweeg.

'n Gedagte wat in 1953 uitgespreek is om die Interkerklike Kommissie te omskep in 'n Adviserende Raad van Afrikaanse Kerke het daarop gedui dat die Kommissie tog nie aan al die verwagtings voldoen het nie. Die Nederduitse Gereformeerde Raad van Kerke was in hierdie tyd van mening dat die samewerking tussen die kerke eerder deur korrespondensie gehanteer moes word (Borchardt, 1974:201). Die saak is verder gevoer en daar is ook besluit om die Interkerklike Kommissie los te maak van die vergaderings van die Nederduitse Gereformeerde Kerk se Raad van Kerke. Hierdie besluit bring mee dat op 10 Mei 1955 die eerste vergadering van die Tussenkerklike Kommissie, soos die liggaam toe bekend staan, gehou kon word. Die Tussenkerklike Kommisie stel dat hy vanaf daardie stadium sal optree as 'n adviesraad van die Afrikaanse kerke" (NHK Argief: Notule TKK, 10 Mei 1955).

Sodoende is die werk van die Interkerklike Kommissie afgesluit en voortgesit deur die Tussenkerklike Kommissie wat hom van meet af sterker sou toelê op die soeke na groter eenheid en samewerking.

Die Interkerklike Kommissie het belangrike werk gedoen en 'n groot bydrae gelewer om inderdaad beter begrip en samewerking tussen die drie Afrikaanse kerke op te bou. Dat daarin geslaag is en dat die gesprek voortgegaan het, dui tog daarop dat dit vir al drie kerke 'n saak van erns was. Dat dit nie altyd ewe maklik was nie, blyk wel uit die geskiedenis van daardie tyd. -Hier kan verwys word na die aanvanklike teësinnigheid van die Algemene Kerkvergadering van die Nederduitsch Hervormde Kerk om met die Interkerklike Kommissie saam te werk omdat die Algemene Kerkvergadering nie oortuig was dat die Nederduitsch Hervormde Kerk deur die ander gespreksgenote as kerk erken word nie. Hierdie probleem word oorkom maar in 1939 is daar weer gespanne verhoudings tussen die Nederduitsch Hervonnde Kerk en die Nederduitse Gereformeerde Kerk vanweë probleme in Bloemfontein en Oos-Londen (Borchardt, 1974: 197). Dan kan ook verwys word na die skerp meningswisseling tussen prof. S.P. Engelbrecht en ds. J.V. Coetzee in die jare 1942-1945 waar dit gegaan het oor die funksie van die belydenis in die kerk (Engelbrecht, 1945:8-9). Net so was daar in 1957 nogal 
spanning tussen die Nederduitse Gereformeerde Kerk en die Gereformeerde Kerk oor artikels in Die Kerkbode en die saak van die betekenis van die begrip susterkerk. Dié saak het so uitgekring dat die Nederduitse Gereformeerde Kerk se Raad van Kerke hieroor in korrespondensie met die Gereformeerde Kerk getree het (Van der Watt, 1987:148-150). Ander geskille en verskille het ook voorgekom, maar dit kon die bande wat inmiddels by die Interkerklike Kommissie gesmee is, nie verbreek nie. Dit dui wel daarop dat die vergaderings van die ampte, in al drie Afrikaanse kerke, 'n belangrike rol speel om 'n moontlike eensydige oorbeklemtoning van 'n enkeling te temper. Op dié manier kon die tussenkerklike gesprek tog voortgaan.

\section{Die Tussenkerklike Kommissie - 1955 tot vandag}

Die Tussenkerklike Kommissie het met sy eerste vergadering in 1955 vasgestel dat dié liggaam driejaarliks sal vergader. Aanvanklik, so wil dit voorkom, wou die Tussenkerklike Kommissie nie veel meer wees nie as net die voortsetting van die Interkerklike Kommissie waar die klem van die bespreking op samewerking geval het. Die sinode van die Gereformeerde Kerk het egter in 1957 'n voorstel aanvaar dat die werksaamhede van die Tussenkerklike Komınissie omgebuig moet word om sodoende daadwerklike kerkvereniging na te streef (Borchardt, 1974:201; vgl. ook Nederduitsch Hervormde Kerk Argief: Notule Tussenkerklike Kommissie, 3 Junie 1958, Bylae A). Nadat die saak bespreek is op die Tussenkerklike Kommissie-vergadering van 3 Junie 1958 is op die Tussenkerklike Kommissie-vergadering van 6 Augustus 1958 besluit dat die afgevaardigdes van die kerke in die vervolg memoranda sal opstel oor die sake wat die kerke uitmekaarhou. Die memoranda sal dan uitgeruil en bespreek word - daarvoor kan bilaterale gesprekke of volle vergaderings van die Tussenkerklike Kommissie gebruik word (Nederduitsch Hervormde Kerk Argief: Notule TKK, 6 Aug 1958). Op dié manier sou uitvoering gegee word aan die aanbevelings van die 1957sinode van die Gereformeerde Kerk.

Die Tussenkerklike Kommissie het vanaf 1958 heelwat aandag gegee aan die saak van kerkvereniging en die struikelhlokke op pad daarheen, maar moes ook aandag gee aan allerlei voorkomende sake wat aandag gevra het (vgl. NHK Argief: Notule TKK, Verslag van die sub-kommissie insake inventaris van samewerking, 29 April 1974). Die feit dat die Tussenkerklike Kommissie in 1958 besluit het om driejaarliks te vergader, het nie bygedra om die saak te bespoedig nie. 


\subsection{Die Tussenkerklike Kommissie se pad na kerkvereniging}

As nou gelet word op die Tussenkerklike Kommissie se bydrae op die pad na kerkvereniging, dan word die ander belangrike aangeleenthede waaraan die Tussenkerklike Kommissie aandag gegee het, nie hier genoem nie.

Die eerste belangrike stap wat die Tussenkerklike Kommissie op pad na kerkvereniging geneem het, is wanneer in 1968 besluit word om in die besonder aandag te gee aan die kerkbegrip én verder aan die Skriftuurlike, leerstellige en kerkregtelike beginsels van ekumenisiteit (NHK Argief: Notule TKK, 13 Junie 1968). Ten opsigte van hierdie aspek is nie net memoranda opgestel en uitgeruil nie, maar indringende bilaterale gesprekke is ook oor die memoranda gevoer. Dit het betreklik gou duidelik geword dat teologiese spraakgebruik en teologiese tradisie 'n belangrike rol in die formulerings van die memoranda van die verskillende kerke speel. Deur middel van die gesprekke is daar inderdaad geslaag om mekaar se teologiese taal te peil en sodoende nader na mekaar te beweeg - dit het in die jare na 1969 veral geblyk uit die indringende gesprekke wat oor ekumenisiteit gevoer is Opvallend is ook die hoë kwaliteit van teologiese gedagtewisseling wat hier gehandhaaf is

Ten opsigte van die eenheid van die kerk word dit duidelik dat die Nederduitsch Hervormde Kerk van mening is dat as daar tussen die kerke 'n eenheid in die Waarheid bestaan, organisatoriese eenheid nie 'n dwingende saak hoef te wees nie (NHK Argief: TKK-Notule, 15 September 1970). Daarteenoor is die Gereformeerde Kerk en die Nederduitse Gereformeerde Kerk daarvan oortuig dat die eenheid in die Waarheid sigbaar moet word in die eenheid van kerkverband. Oor dié saak is belangrike en insiggewende studiestukke opgestel wat tot dusver nog nie in besonderhede uitgespel het wat presies die eenherd in die Waarherd is of moet wees nie (vgl. NHK Argief: TKK Notule, 4 Oktober 1982). Die gesprekke vorder ook nie altyd vinnig nie omdat daar "... na konsensus van opinie gesoek word" (NHK Argief: TKK Notule, I Oktober 1973). Die betreklik stadige vordering, wat saamhang met die feit dat vanaf 1968 wel jaarliks vergader is, dui enersyds op versigtige deeglikheid in die memoranda en aan die ander kant op die eerlike pogings om mekaar reg te verstaan.

Hierdie stand van sake het die Algemene Sinode van die Nederduitse Gereformeerde Kerk in 1966 daartoe gebring om te verklaar dat:

Die interkerklike kommissies wat daar bestaan tussen hierdie kerke is te berustend en rustig in hulle houding om enigsins daadwerklik op te tree en die kerke self te dadeloos ten opsigte van hulle onderlinge verhoudings (vgl. Van der Watt, 1987: 153). 
Hoewel in hierdie teregwysing heelwat waarheid steek, bly die feit staan dat dit veel beter is om langsaan én deeglik die pad te verken as om soos in 1882 gebeur het, ' $n$ oorhaastige vereniging te probeer bereik wat nie kan standhou nie. Inmiddels het die gesprekke oor eenheid en ekumenisiteit al verder uitgekring sodat ook kerkeenheid oor nasionale grense aan die orde gestel is.

Daarom word in 1977 besluit om meer spesifiek oor die kerk en die kerkregering te praat (NHK Argief: TKK Notule, 9-10 Augustus 1977) om sodoende die saak van eenheid te dien, maar twee jaar later word daar, 'n bietjie moedeloos gekonstateer "ons praat by mekaar verby" (NHK Argief: TKK Notule, 26 Oktober 1979). As die saak verder ontleed word, blyk dit dat 'n wortelprobleem die verskil in Skrifbeskouing is.

Die saak word nie as ' $\mathrm{n}$ afsonderlike probleem hanteer nie maar ingepas in die bespreking van 'n baie breër tema: Ons Calvinistiese erfenis - 'n tema wat dan dogmaties, volkekundig, staatkundig, kultuurmatig en vanuit die etiese hoek beskou sou word. Die breë tema vir die tagtigerjare het egter nooit werklik so breed aan die orde gekom nie. In die plek daarvan het kerkordelike memoranda en die saak van die Skrifbeskouing die aandag gevra (NHK Argief: TKK Notule, 22 Oktober 1980). Uiteindelik het die werksaamhede van die Tussenkerklike Kommissie in die tagtigerjare in twee onderkomitees gestalte gekry: die sogenoemde kerkbegripkomitee en die Skrifbeskouingkomitee. Albei komitees het baie wyd gewerk, omvattende en indringende memoranda opgestel en bespreek. (Hier kan verwys word na Nederduitsch Hervormde Kerk Argief: TKK Notule, 3 Aug 1982, asook die vergadering van die Onderkomitee 20 Oktober 1982 en die Onderkomitee: Skrifbeskouing, 10 Maart 1983.) Op 23 Maart 1985 word vasgestel:

Dit is duidelik dat te midde van die verskille op die verskillende vlakke, belangrike punte van ooreenkoms bestaan én dat praktiese en nie prinsipiële oorwegings nie, soms ten grondslag van die verskille lê. Die verskil oor die kerkbegrip (eenheid en verskeidenheid), kerkverband (die belewing daarvan) en die sendingopvatting lê hoofsaaklik ten gronslag van die verskille.

Juis in hierdie tyd het die Tussenkerklike Kommissie self sy voomeme herbevestig toe gestel is dat "... sy uiteindelike doelstelling, eenwording van ons drie Afrikaanse kerke is" (NHK Argief: TKK Notule, 23 Maart 1983).

In die gesprekke op die Tussenkerklike Kommissie het dit mettertyd duidelik geword dat die Onderkomitee: Skrifbeskouing se vordering nie maklik of vinnig sal wees nie omdat dit nie so maklik was om konsensus te bereik oor tekskritiek, teksvasstelling en Skrifkritiek, die Bybel as Woord van God, die aard van Skrifgesag en dergelike meer. Die Onderkomitee: Skrifbeskouing het op sy vergadering van 14 Augustus 1984 die oorsprong van die verskille soos volg aangedui: 
Die verskille kom voor uit kerkverskille, individuele verskille, vakverbondenheidsverskille en teologiese inrigtingverskille. Die feit dat die belydenisskrifte se interpretasie nie dieselfde is nie, bring mee dat daar soms ' $n$ vermoede bestaan dat die belydenisskrifte nie oral hoog genoeg aangeslaan word nie. Die a-prioriese denke speel ook hier ' $n$ rol. Die voortgaande gesprek skep egter die geleentheid om mekaar beter en juister te verstaan.

Daarmee het die Subkomitee ' $n$ saak van belang aangeroer en dit is dat in die vergaderings soms vergeet word dat dit 'n gesprek tussen kerke is en nie 'n gesprek tussen teoloe en vakgenote nie. Uit die aard van die saak loop die sake hand aan hand, maar die vraag ontstaan soms of die gesprekke nie onnodig geproblematiseer word nie sodat daar geen werklike vordering is nie. Tog is elke keer weer besluit om die gesprek voort te sit en die gestelde doelwit na te strewe.

In die dekade van 80 is daar geweldig baie werk gedoen deur die twee onderkomitees en die kwaliteit van die memoranda en gesprekke het steeds saaklik, indringend en insiggewend gebly. Belangrike memoranda wat behandel is, is byvoorbeeld die Memorandum van die Drie Teologiese Fakulteite van die NG Kerk oor Skrifgesag en Skrifgebruk (NHK Argief: TKK Notule, 22 Augustus 1985).

Samevattende memoranda wat ooreenkomste en verskille uitgewys het, is veral deur die Onderkomitee: Kerkbegrip voorgelê. Oor hierdie aangeleentheid het die Subkomitee die volgende gestel (NHK Argief: TKK Notule, 5 Maart 1986):

Tussen die drie kerke bestaan daar ' $n$ algemene konsensus dat die Woord van God en die Gereformeerde Konfessie die enigste basis van die gesprek is en behoort te wees - veral ook die gedeeltes of artikels in die belydenisskrifte wat oor die kerk handel. Die feit dat die drie kerke met mekaar oor baie sake saamstem, is juis hieraan te danke.

Hoewel die drie kerke hulle onderwerp aan die gesag van die Skrif en aan ' $n$ binding aan die Konfessie, is daar soms verskille ten opsigte van die interpretasie van die Skrif en Konfessie. Hierdie en ander verskille word soms ook veroorsaak deur die invloed van verskillende kerklike tradisies en teologiese stromings. Ten spyte van punte van verskil, is daar by al die kerke ' $n$ gesamentlike waardering vir en gebondenheid aan die Reformatoriese erfenis.

As dié standpunt vergelyk word met die opvattings en menings wat in die verskillende kerke van mekaar gehuldig is gedurende die twintiger- en vroeë dertigerjare, dan word dit duidelik dat daar al ver gevorder is op die pad na kerkvereniging. In 'n sekere sin is dit jammer dat al die studiestukke en memoranda wat by die Tussenkerklike Kommissie behandel is, nie in die hande van elke kerkraadsvergadering in die drie Afrikaanse kerke geplaas kon word nie. So 'n poging sou aan die interkerklike gesprek nie net 'n breër klankbord gee nie maar ook al 
die gelowiges in die kerke bereik sodat hulle ook die gesprek kan volg (vgl. NHK Argief: TKK Notule: Memo van die NGK oor die TKK, 18 Sept. 1989). Aan die einde van die dekade van ' 80 het sowel die Onderkomitte: Kerkbegrip as die Onderkomitee: Skrifbeskouing volstandige samevattende memoranda oor hulle werk opgestel en het al drie kerke se sinodes besluit dat die gesprek voortgesit moet word. Daarby is daar ook verdere vraagstukke vir studie en bespreking aangedui.

\section{Afsluitende opmerkings}

Die Tussenkerklike Kommissie, die middel om die interkerklike gesprek aan die gang te hou, het gedurende die bietjie meer as vyf dekades van sy bestaan, merkwaardig baie gedoen om beter begrip en samewerking tussen die drie Afrikaanse kerke te bewerkstellig en in stand te hou. Daarby kan gestel word dat die Tussenkerklike Kommissie ook die beweging na kerkvereniging lewend gehou en gestimuleer het. Tog moet in alle realisme gestel word dat die Tussenkerklike Kommissie se sukses, as oor kerkvereniging gepraat word, nie so hoog is nie miskien omdat die Tussenkerklike Kommissie nog nie self presies vasgestel het wat voldoende eenheid vir kerkvereniging moet of kan wees nie. Een of ander tyd sal die Tussenkerklike Kommissie ernstig aandag moet gee aan die weeg van die ooreenkomste en verskille wat nou reeds bereik is.

Dit is dus redelik om te sê dat kerkvereniging, moontlik gemaak deur die Tussenkerklike Kommissie, nog nie ' $n$ nabye aangeleentheid is nie. Die dekade van 90 sal waarskynlik ook nog toegewyde en volgehoue dink- en onderhandelingswerk vereis voordat die saak van kerkvereniging werklik aan die orde gestel kan word. Miskien moet hierby in gedagte gehou word dat die veranderinge wat op die oomblik in Suid-Afrika aan die gang is, ook ' $n$ invloed op die tussenkerklike gesprek kan hê. Die vinnige sekularisasie van die samelewing, die redelik aanskoulike ineenstorting van morele waardes en die steeds toenemende gewelddadigheid saam met die verarming van die gemeenskap, kan die kerke dalk dwing om vinniger nader na mekaar te beweeg - of dit kan die teenoorgestelde uitwerking hê.

Die feit bly egter, as so formeel gekyk word na die werk van die Tussenkerklike Kommissie en sy voorganger die laaste 55 jaar, dat daar al groot winste behaal is en dat daar alreeds ' $n$ taamlike breë en hegte basis bestaan waarop die drie Afrikaanse kerke kan voortgaan met die onderlinge gesprek en die strewe na groterwordende eenheid. Tog sou dit onrealisties wees om die struikelblokke te negeer of te verkleineer, daarom moet daar gekonkludeer word dat daar hard gewerk sal moet word om die struikelblokke te oorwin, want die ideaal waarna gestreef word, eis dit van die drie Afrikaanse kerke. 
In 1892 kon die Nederduitsch Gereformeerde Kerken en die Christelijke Gereformeerde Kerken in Nederland betreklik gou en maklik by 'n kerkvereniging uitkom wat verreweg die grootste deel van die lidmate van die kerke verenig het (Rasker, 1974:190).

In 1885 het die Nederduitsch Hervormde Kerk en die Nederduitse Gereformeerde Kerk in die Zuid-Afrikaanse Republiek 'n poging tot vereniging aangewend wat 'n verwydering tussen die Nederduitsch Hervormde Kerk en die Verenigde kerk geskep het wat selfs vandag nog nie volkome oorbrug is nie.

Inmiddels is daar egter 'n struktuur waarmee die drie Afrikaanse kerke die gesprek oor kerkvereniging kan voortsit. Die gesprek, wat in sekere opsigte sy eie momentum ontwikkel het, dreig soms om te vervlak na 'n debat tussen teoloë in plaas van 'n debat tussen kerke. Daarom sal dit miskien, te midde van al die ander sake, nodig wees om die vraag te vra: hoe groot moet die onderlinge kerklike eenheid wees voordat daar werklik van kerkvereniging gepraat kan word?

Hoe dit ook al sy: die nadenke oor die kerkvereniging van 1892 beklemtoon andermaal dat die drie Afrikaanse kerke met die Tussenkerklike Kommissie hulle voet op 'n pad gesit het waarop hulle nie sommer so sal kan omdraai nie.

\section{Bibliografie}

BAKHUIZEN VAN DEN BRINK, J N. et al. 1962. Documenta reformatoria Kampen : J H Kok N V

BORCHARDT, C.F.A. 1974 Die betrekkinge tussen die drie Afrikaanse kerke Ned. Geref. Teologiese Tydskrif, XV(3): 181-203

BOTES, H J 1989. Ds LE Brandt (1873-1939) as kerklike leier en bouer Ongepubliseerde DD-proefskrif, Universiteit van Pretoria

DE JONG, O 1978. Nederlandsche Kerkgeschiedenis. Nijkerk : Callenbach B V

ENGELBRECHT, S.P 1945. Neo-Calvinisme Ontwikkeling en afwyking Pretoria: JH de Bussy

JOOSTE, J P 1958 Die geskiedenis van die Gereformeerde kerk in Suid-Afrika 1859-1959. Potchefstroom

NEDERDUITSCH HERVORMDE KERK ARGIEF Notules van die TRK, 1955-1989

RASKER, A J 1974 De Nederlandsche Hervormde Kerk vanaf 1795 Kampen : J H Kok

REITSMA, J \& LINDEBOOM, J 1949. Geschiedenis van de Hervorming en de Hervormde Kerk der Nederlanden 's-Gravenhage Marinus Nijhoff

VAN DER WATT, P B 1983. Die Ned Geref Kerk en die Susterkerke (/n Van der Watt, P B red Die NG Kerk en sy ekumeniese verhoudinge Pretoria : Universiteit van Pretoria p 2-15)

VAN DER WATT, P B 1987 Die Nederduitse Gereformeerde Kerk 1905-1975 Pretoria NG Kerkboekhandel

VAN VEEN, S D 1904 Eene eeuw van worsteling Groningen : J B Wolters 
